\title{
Social Commitment: A Vision for Higher Education $^{1}$
}

Sheryl Riechmann Hruska

University of Massachusetts

Concern for the future joins all people. Hearts long for safety, health, nurturance, community and growth. Divided by national boundaries, prejudice and points of view, the human race has not done well at providing these necessities for ourselves or the generations to come.

The success of the human race lies in the well-being and peace of mind of each person and community. Science and technology, power and money have contributed little toward this end. Yet, progress must be made.

It is questionable whether any of our existing institutions can do much to change our situation. However, if there is one, I think it is education. Here, I will be focusing on higher education for it is the designated source for the creation of new knowledge and the perpetuation of humanitarian values.

In this paper, I present a perspective on some of the dynamics that need urgent attention if higher education is to facilitate growth and enrich the human condition. I also offer suggestions about specific actions we can take now to become more effective facilitators of positive change.

\section{THE SOCIAL CONTEXT}

As countries adopt technology and bureaucratize production, changes occur as to who and what is valued. Consider 
the following examples of what we can observe in "developed" and "developing" countres:

-Quantitative and technical information and language becomes increasingly valued along with those who know this information or how to talk this language (i.e., highly educated people, most often males of the dominant race or ethnic group). Certain occupations also become more highly valued (e.g., engineering, computer science).

-Qualitative information, feelings and intuition become suspect and devalued, along with those who operate with these as a central feature of their information base (i.e., many women and ethnic groups). Again, this is reflected in the lack of value placed on certain professions (e.g., human services, child care).

-Breaking problems and information into discrete parts is valued more than looking at things holistically, interdisciplinarily and in terms of long-term implications on other related elements. This occurs to the detriment of certain types of learners, women and ethnic groups who tend to view problems and the world in a social context and holistic fashion (Messick, 1976; Chesler, 1972; Gilligan, 1982; Miller, 1976) and to the detriment of certain problems that suffer from being studied in discrete parts (e.g., pollution, schooling and families).

-A highly educated few are seen as having the information and knowledge "that matter" and the wisdom to use these for the betterment of daily life and the progress of the country.

-Respect for the integrity and importance of nature fades as the perceived need for materials to fuel technological advancement increases. Notions of nature as a teacher, as the protector of the planet get lost as experts elevate their ideas and their importance as the saviors of the human race (or at least the lives of many in their own country).

-The acquisition of things becomes an end in itself and 
the impact of this on relationships and family ties gets overlooked or devalued.

From these examples, we can see that expertise, information, knowledge, and wisdom are defined in a social context. Prevailing prejudices about these have far reaching consequences on the status and quality of life of millions.

Higher education seems not to acknowledge these prejudices. Much of the academy seems unaware or uncaring about how it perpetuates them and is limited by them. Yet, what is taught, who is taught, and who teaches are all inextricably interwoven with these prejudices and definitions.

Though higher education has the potential directly and indirectly to facilitate the development of all people, it has not taken seriously such a task, nor has it accepted the global scale of this need. The content expertise found in universities and colleges is only part of what is needed from higher education today. The possession of information alone cannot be seen as a virtue (Brown, 1986; Noddings, 1984). We need to define and deliver education in ways that unite people in the commitment to use what they know to enhance the development of others.

\section{HIGHER EDUCATION AND A SOCIAL PURPOSE}

Many who have written of the aims of education have set for us a social purpose (e.g., Dewey, 1964; Eble, 1983; Noddings, 1984). However, the search for appropriate aims often gets posed in either/or terms-vocational education vs. liberal education, sciences vs. humanities, technology vs. the liberal arts. Philosophers have argued in this vein, as have academic departments in their competition for resources and status. This way of framing the search for aims is limited on four interrelated counts.

\section{The How and Why of Education}

The argument framed in terms of disciplines defines higher education by what is taught and fosters arguments over what content is most important to know. The assumption seems to be that the acquisition of certain content, or consideration of certain theories will in itself lead to wisdom. 
What can be ignored in this framing is the "how and why" of higher education. Without attention to desired outcomes and the quality of teaching and learning, we can have higher education that equals a simple accumulation of facts, concepts and theories that neither inspires nor enlightens. As Whitehead (1967) noted decades ago, there is no greater bore than a merely well-informed person. I would add, that besides being boring, such persons represent a loss in the potential development of the world.

Higher education must concern itself with how people use information and grow from its application. We need to attend to outcomes (e.g., educated, socially responsible world citizens) and how to achieve those outcomes. A focus on academic content is simply not enough.

\section{Importance of Context}

The either/or content debates overlook context. Information and education are treated separately from the environment. If one assumes, as do Dewey (1948) and Eble (1983), that education must address itself to practical ends and the growth of all people, then existing needs and problems become a guiding factor in the shaping of the educational endeavor.

In any country, at a particular time, many problems exist that limit the development of its residents and which need urgent attention (e.g., population growth, famine, pollution). For example, in the case of agriculture in the United States, the Morrill Act of 1865 and the consequent development of the land grant colleges led to increases in agricultural productivity. If socially responsible legislative action were to occur today in the wedding of agriculture and higher education, the focus might well be on participative rights regarding land usage or food distribution rather than production.

The problems of today are often international, and more socio-political or economic than technical. Yet, higher education has not reorganized itself to address these larger and more far-reaching problems. The academy operates in disciplinedefined departments that have changed little in recent decades. We have yet to bring together our collective perspectives on issues of urgent need.

Defense department funding, foreign aid and industry 
generate strong pressure on the selection of problems to be studied. Higher education has in many cases succumbed to these pressures. Broad aims of social development get traded for work on technical problems that may well serve the principle investigator's equipment supply and the funder more than those who are without the finances to buy attention to their needs.

Higher education needs to recontact the people and problems of the world. Discipline-defined faculty and curricula may limit our ability to work effectively on the multi-faceted problems of today.

\section{Social Consciousness}

The either/or disciplinary argument fails to address the need for each educator to have a social consciousness. It may be easy to see why we want those in the sciences to address in their teaching and research the social and environmental impact of their work. It may be harder to see why the notion of social responsibility is as vital in the humanities, liberal arts and professional schools. In a different, but no less important way, lack of social responsibility is as dangerous here. Historians, educators, business professors, for example, each paint a picture of past, present and future life. Both by overt action and omission, people in these fields can fail to help their students develop a humane, rounded and socially committed perspective on their profession and the world. They can instead help produce pedants, albeit highly intelligent pedants, and bigots.

Through such behaviors as prejudice in selecting events and authors, failure to address ethics, showing disrespect for alternative points of view, modeling discriminatory language or practices and failing to encourage concern for others, we send from our colleges people who reflect a limited notion of education. We send forth people with no vision and commitment to help others grow. They are unconcerned about the consequences of their work on others and unprepared to benefit from different perspectives. 


\section{The Hidden Curriculum}

Discipline-based thinking overlooks the person teaching the content. The importance of the hidden curriculum has been noted by many authors (Illich, 1971; Friere, 1970; Bowles \& Gintis, 1976). The power it wields resides in the world view of the teacher and how students are treated. Faculty who see books or the laboratory as their lives will surely provide different perspectives and information than faculty who have active interests outside their disciplines and who are concerned about their students and social issues. In the first instance, we are likely to see content as the beginning and end of the lesson. In the latter, we are likely to see exploring the content as a more interdisciplinary endeavor and as a means for facilitating personal and social development.

Higher education does little to help faculty develop in socially pro-active and interdisciplinary ways. We educate and evaluate our faculty in terms of content. For the most part, faculty (and their students) have not received an education designed to help them acquire a global perspective and social commitments. Faculty are left on their own to find the desire and means to such a broad education and to find it over and over again as the social and technical context changes.

Lack of emphasis on the hidden curriculum deters us from seeing the importance of ongoing personal and professional development of faculty and the need to study classroom interaction. Greater resource commitments to expanding the world view and social sensitivity of faculty members could go a long way toward enriching the nature of education students receive. If more faculty lived with greater compassion, cultural awareness, enthusiasm and generalist-leanings, then we may be in a better position to live up to Dewey's broad social aim for education "to set free and to develop the capacities of human individuals without respect to race, sex, class or economic status" ... "to educate every individual into the full stature of his (sic) possibility" (1948, p. 186).

Out of the concerns above comes a call for change. We need to keep our aims closely tied to global human and environmental development. In this light, we need to look hard at how we in higher education utilize the information at our disposal and how our students use it as well. The means by which we 
accomplish our work must contribute to a foundation for community, mutual respect, and growth within and across national boundaries We need to build organization cultures and structures that more readily nurture interdisciplinary effort to deliver on a healthier vision for the future. In other words, the needed changes must occur personally, professionally and organizationally.

\section{IMPLICATIONS FOR ACTION}

To bring about this realization of a global, socially-based goal for education, changes need to occur on several fronts and levels.

\section{Individual Faculty}

If one accepts the aim of education to be the exploration and utilization of information to better the lives of all living things, then indeed we must each join in educational activity based on concerns and commitments that cross national boundaries and that draw sustenance from a personal commitment to furthering or enriching life. Our personal, inner development or understanding is extricably united with the choices we are called to make daily in carrying out our educational and research activities. We cannot afford to be unself-examined, narrow, prejudiced and simply competent purveyers of our disciplines. To be so is to not be able to raise ourselves to the scale of current problems or to inspire others to this larger cause. If individuals, communities and the planets are to develop in the best sense of that word, then we must more zealously commit ourselves to such expanded aims and self development. We must each see ourselves as one source, united with others, for creating a better world.

Specific ideas for action include:

-Incorporate teaching methods which are democratic in their assumptions and practice (i.e., experiential and interactive methods such as simulatons, cases, discussions, and group problem solving). Autocracy in the classroom makes for passivity and acceptance of authoritarianism elsewhere. Furthermore, given the complexity of problems facing us, we need to cultivate collaborative efforts at knowledge development and utilization. 
-Include interpersonal outcomes in our teaching. We can teach content and also commitment to its ethical and moral use. We can help shape skills for communication, problem solving, and community building.

-Discover and eliminate the prejudices we hold. Each of us was carefully taught verbally and non-verbally by our families and the larger society to value some people more than others. These learned notions can be unlearned. We can come to value all human beings.

- Review research designs and course syllabi for hidden prejudice. Look at the race and sex of authors we cite and the world view they offer. Are we providing a mix of perspectives? Are we offering views that build toward greater human understanding?

-Step back and assess the world-view or paradigm from which we work. Our professional perspective, critique and commentary are all imbedded in or reflective of a paradigmatic stance. If we know our orientation and the options to it, we will be more rounded and perhaps better able to understand the views of others.

-Be generous and respectful in all our interpersonal interactions. Treat peers, secretaries, custodians and students as valuable human beings. Acting from a "caste" perspective within the institution models acceptance of a caste system in the larger social setting.

-Become knowledgeable about the literature on perceptual and learner differences (e.g., learning styles, gender, cultural orientations). With an appreciation of these differences, we can refrain from the impulse to label negatively behaviors that differ from our own.

-Increase the time and value given to joint and interdisciplinary scholarship. Give value to the growthenhancing outcomes of professional work, rather than simply assessing journal titles and grant amounts.

\section{Faculty Development Facilitators}

In my experience, faculty development facilitators often interact with faculty in ways that promote the myth of valuefree content and courses. We may unwittingly collude in the 
delivery of education that enhances learning, but learning of little value to the person or the well-being of the world. I urge us to step out of a cloak of neutrality and act from a more socially responsible perspective. For example, in our work with faculty, we can jointly consider the items in the previous section plus ...

-Review texts and references regarding gender and cultural representation.

-Explore reference material, teaching methods and classroom interactions for the values they promote (e.g., competition, collaboration, cultural pluralism, elitism) and discuss the values which might contribute to improved living conditions and well-being of all people.

-Examine the applications which students are asked to make of course content. Are the applications ones which ready students to work on social problems, to take ethical stances in the work place and to see themselves as able to make a contribution to bettering the human condition?

-Note examples of prejudice and affirmation in classroom interactions.

-Support faculty members who want to offer courses related to social visions, problems or issues (e.g., the politics of food, peace and war, the philosophy and politics of science). Bring faculty together who might be interested and able to deliver interdisciplinary courses on such problems and new visions.

-Expand our own reference material to include literature on social issues in teaching and higher education.

\section{Administrators}

Faculty behavior, student-to-student interaction and campus climate contribute to student attitudes, values, knowledge and behavior. Movement toward the graduation of students with global perspectives and the skills to act in socially responsible ways can start to shift the views countries hold of each other and the forces of oppression that smother people throughout the world. As administrators we can help institute practices and policies that support not only growth for students but 
others inside and in contact with the campus. For example, we can:

- Reward faculty and provide financial support for the development of interdisciplinary courses which address world problems and visions for a healthier world.

-Sponsor institutes and consultants to help faculty review their scholarly and teaching activities in terms of social issues and needs. Do the same for others in the institution regarding how they do their work.

-Actively sponsor and promote affirmative action in attracting and retaining a culturally diverse faculty and student body. Model this in our own staffing patterns and practices.

-Encourage, finance and reward cross-cultural and transnational dialogue, research and exchanges of faculty and students.

-Review the mission of the institution and be sure a commitment to enhancing the human development of all is visible and supported throughout the institution.

-Encourage and reward the redesign of curricula and academic programs which more directly address social issues and prepare students to act in socially responsible ways.

-Support faculty in obtaining funding which will result in environmentally and humanly healthy outcomes. Do not let funding-source options dictate institutional mission and activities.

\section{CONCLUSION}

In all our actions, we contribute to the shape of the future. As educators, our attitudes and behaviors get reproduced and multiplied through the actions of our students. Our new information, techniques and technology shape the lives of many we will never see.

Pressures toward specialization, reductionism, nationalism and bureaucracy can easily detract us from a commitment to collaboration, human rights and a world community. Because of prevailing norms and habits, even the actions suggested above 
can involve risk. Those actions often involve being different from the norm and speaking out for different professional standards and activities.

Changes of the nature and scope proposed in this paper are not easy. Soul searching, behavior change and organization redesign are all part of it. Success will come more readily if we join with others in these efforts. Here and abroad we can strengthen our commitment to a vision of growth, love and sustenance for all. We must start acting now to make this vision the reality experienced by us and future generations.

\section{REFERENCES}

Bowles, S., \& Gintis, H. (1976). Schooling in capitalist America. New York: Basic Books.

Brown, D.W. (1985). Professional virtue: A dangerous kind of humbug. Change, Nov.-Dec., 8-9, 46-47.

Chesler, P. (1972). Women and madness. New York: Doubleday.

Dewey, J. (1948). Reconstruction in philosophy. (Enlarged Edition) Boston: Beacon Press.

Dewey, J. (1964). The need for a philosophy of education. In R. Archambault (Ed.), John Dewey on education, selected writings. New York: Modern Library, 3-19.

Eble, K. (1983). The aims of college teaching. San Francisco: Jossey-Bass. Freire, P. (1970). Pedagogy of the oppressed. New York: Seabury Press.

Gilligan, C. (1982). In a different voice: Psychological theory and women's development. Cambridge, MA: Harvard University Press.

Illich, I. (1971). Deschooling society. New York: Harper \& Row.

Messick, S. \& Associates. (1976). Individuality in learning. San Francisco: Jossey-Bass.

Miller, J.B. (1976). Toward a new psychology of women. Boston: Beacon Press.

Noddings, N. (1984). Caring: A feminine approach to ethics and moral education. Berkeley, CA: University of California Press.

Whitehead, A.N. (1967). The aims of education and other essays. New York: The Free Press. (Original Copyright 1929 by the MacMillan Company).

\section{NOTES}

1. This paper is based on a paper presented at the Visions of Higher Education: TransNational Dialogues, Stockton, New Jersey, August, 1985. 